\title{
MANAGEMENT STUDIES IN BRITAIN
}

$\mathrm{T}_{\mathrm{H}}^{\mathrm{H}}$ HE frequency with which reference has been made in recent debates in Parliament to the quality of management and the desirability of training for management gives special interest to two recent broadcast talks on management and the universities. It was particularly noticeable in the debate in the House of Commons on July 26 on the economic situation, although the Chancellor of the Exchequer himself, in opening the debate, merely referred to a re-arrangement of priorities in favour of scientific and technical education and expressed his dissatisfaction with the progress being made in training skilled labour. $\mathrm{Mr}$. P. Walker, however, urged that more attention should be given to commercial education; it is not enough, he said, to increase the supply of scientists and technologists if this is not balanced by sufficient skilled administrators to ensure efficient industrial management; this plea was strongly supported by Mr. J. Diamond and Mr. R. Gunter, both in this context and in its bearing on improved industrial relations. Indeed, both Mr. G. Brown and Mr. D. Howell attributed part of our present difficulties directly to bad management. Less was made of this point in the debates on Britain and the Common Market in both Houses of Parliament on August 2 and 3, but whether or not Britain enters the European Common Market, considerable changes in the industrial life of Britain are inevitable, and these will make large demands on management. Lord Poole indeed was confident that in any event most of British industry would be able to deal effectively with competition from Europe or elsewhere; but, while Lord Plowden also believed that large parts of British industry are highly efficient and competitive, he also thought that it is doubtful whether, in certain industries at least, the United Kingdom offers, on its own, a market large enough to support units of the most economic size.

It is certainly true that, if Britain is to take advantage of the opportunities which entry into the Common Market would offer, industrial management must be competent to meet the most searching demands for efficiency. Nor is management likely to be adequate to meet the situation alone, although, as Mr. D. F. Hutchison pointed out in a broadcast talk on authority and the individual in industry (Listener, Feb. 2, 196I), the management function is essentially an autocratic one which should be clearly differentiated from the function of a trade union. It is indeed this conflict between management and the unions that retards the vital function of taking decisions, and although Mr. Hutchison sees such conflict as inherent in the industrial situation, he insists that it should be constructive conflict. He does not suggest that the managerial function should be weakened-that indeed would be detrimental to the trade union members themselves in the long runbut it follows that in his view it is a vital test of the competency of management that it should, while in no way yielding its power to take decisions, fully safeguard the rights and personality of individuals and secure, so far as possible, the understanding and co-operation of all concerned.

Mr. Hutchison was concerned both that management should be effective and dynamic, and that the trade unions also should exercise their proper function and regain the ground they have lost with the community. His talk thus provides an interesting introduction to the two talks some months later on management and the universities, in that he emphasized practical points that lie rather outside the scope of either Dr. V. L. Allen or Mr. J. H. Smith's talk (Listener, July 13). Mr. Allen, like Mr. Hutchison, recognizes the inherent conflict of interests in industry, and because social scientists have tended to ignore this question of power and conflict, he is inclined to reject the whole idea of management training or studies as at present practised in the universities. Management, he argues, is not a self-contained activity; it is a single layer of control in a hierarchical structure involving power relations in industry and power and status relations in the community at large, and nothing makes sense unless due account is taken of these relations. It might be interpolated that some status relations in industry also need to be recognized. Furthermore, Mr. Allen rejects, perhaps too procipit. ately, the idea that any body of knowledge about the subject is being built up; little serious research has been done and less has involved structural or comparative analysis.

If Mr. Allen is right here, it is indeed difficult to maintain that management meets the requirements for an academic discipline sufficiently to justify its being taught in universities. He dismisses, too, the idea that the study of management is vocational, and he is highly critical of all three main methods of teaching management which are in use. In so far as managers can be trained, he suggests that they should be trained through other firms and outside agencies, such as technical colleges, and he would a]ter both the substance and direction of existing management courses in the universities. Recognizing that industrial behaviour as a whole must be studied if any part of it is to be properly understood, he would give priority to large-scale comparative studies, which should yield results of value both to management and to trade unions, and from which, ultimately, a sociology of industry would emerge, standing in its own right as an academic discipline, and which could be taught openly and honestly and usefully in our universities.

Mr. J. H. Smith (Listener, July 20) takes the opposite view. Management studies in British universities, he maintains, deserve much more prominence than they have had so far, both on academic grounds and in terms of what universities could usefully do to raise standards of management in British industry. The most urgently needed development is a strong postgraduate business school, mixing graduates from different disciplines and focusing attention on a common core of subjects which illumine the principles and practice of management. Such a school should be part of a university already strong in the social sciences, but it could be closely linked with other postgraduate administrative studies, notably in public and social administration, which are already well established in some universities.

$\mathrm{Mr}$. Smith points out that it is now widely recognized that the social sciences can be regarded as 
having the same bearing on the practice of management as the natural sciences have on the practice of medicine, and agrees that research in industrial behaviour is an indispensable condition of the growth of management studies. He thinks Dr. Allen is too pessimistic as to the amount and extent of fundamental research in this field. $\mathrm{He}$ does not believe that the universities are pushing ahead too quickly and too uncritically. On the contrary, he considers that the new developments give an impression of caution and of conscious experiment: published plans seem prudently tentative, taking different starting points, and ready to try new combinations of disciplines and unfamiliar disciplines.

By and large, the picture of the present position which Mr. D. Freeth, Parliamentary Secretary for Science, gave in the debate in the House of Commons on August 4 on the need for a social sciences research council seems to support Mr. Smith's view rather than that of Dr. Allen. Moreover, Mr. Smith suggests that much of the impetus towards education for management derives from industry's wish to broaden the intellectual outlook of its managers, to take an outside view of the industrial system, particularly in its social and international context. $\mathrm{He}$ challenges Dr. Allen's assertion that the universities are simply seeking to meet the desire of the managers to know how to manipulate a labour force under full employment.

The demand for higher education bearing on management is a direct consequence of the growth of large organizations in industry and commerce, and in public administration. The complexities of these organizations pose problems of a high intellectual order: how to control and co-ordinate individuals responsible for diverse activities, how to direct and re-shape these activities in response to technical, economic and social change, how to deal with an increasingly literate and independent labour force. The administration and organization of scientific research and the problems of Government and science are a particular example where there is need for constructive and creative thought and experiment. Mr. Smith points out that if the universities do not take up this challenge, industry must almost certainly attempt to do so alone, and there will then be little chance either that management studies will be liberated from the framework of discussion fixed by industry itself or that the whole subject will be studied with the freedom and objectivity it deserves.

Accordingly, he takes the view that the universities should move much faster; that they are already in a position to develop management studies much more vigorously if they wish; and that there is a core of subjects now generally agreed to be relevant, and a growing body of research findings to provide, inter alia, material for a critical understanding of the industrial system in general, and the management function in particular. He sees nothing in the programmes of existing courses in Britain or in the attitude of those teaching them, which suggests a departure from the high standards claimed for the universities, nor does he believe that real weight is now attached to social harmony rather than conflict, or that social scientists are eager to help managers to manipulate behaviour.

Dr. Allen's objection that management education is directed towards producing an élite is treated as more substantial. Many of those receiving it will come to occupy positions of considerable authority and exercise power in large measure over their fellow human beings. The view they take of their responsibilities is a matter of the utmost concern to society, and the role of the universities in shaping that view is highly important. Mr. Smith is undoubtedly right in suggesting that this is no reason for suggesting that the universities should move still more cautiously in this field: rather it is a reason for them coming to terms with management education, and quickly. The real question is not whether there will be a management élite but what sort of élite it will be. If, as seems certain, this elite is increasingly educated in the universities and in the colleges of technology, it follows that those institutions must pay more attention, through research and teaching in the social sciences, and through education for management at the postgraduate-level, to the world in which this increasing proportion of their graduates will spend their working lives. A recent statement issued by the Manchester College of Science and Technology, in connexion with Mr. R. B. Dew's appointment as first visiting professor in industrial administration from October 1 , is worth noting here. The statement indicates that the College hopes to expand the work of the Department under Prof. R. W. Revans and affirms $a$ strong belief in the value of management studies. The College believes that a university can make three distinct contributions. First, by its own research, the study of the problems of management and analysis of the consultant's case-book to extract basic teachable ideas; secondly, by communicating these ideas to students so as to encourage them to seek the underlying structure within which the problems of management may be more fully identified and progress more readily controlled; and thirdly, to study the actual processes of management. That statement is both in accord with the general sense of the debate in Parliament on August 4 and with Mr. Smith's argument rather than that of Dr. Allen.

\section{INDUSTRIAL RESEARCH IN BRITAIN}

$R$ ESEARCH FOR INDUSTRY 1960, follows the same pattern as the past three reports on the industrial research associations in the Government scheme*. The report of the Industrial Grants Committee is followed by a review of the achievements - Department of Scientific and Industrial Research. Research for Industry 1960: A Report on Work done by Industrial Research Associations in the Government Scheme. Pp. iv $+148+12$ plates. (London: H.M.S.O., 1961,) 88, net. of the 10 research associations, the terms of grant of which came up for review during the year, and two chapters in which Dr. A. H. Sully reviews the contributions of the research associations to health and safety, and Dr. T. Moran the position of food research in the United Kingdom, including the role of the research associations. The remainder of the report (roughly two-thirds) comprises a list of the associa- 